\title{
COMPETITION FOR NITROGEN DURING MINERALIZATION OF PLANT RESIDUES IN SOIL: MICROBIAL RESPONSE TO C AND N AVAILABILITY
}

\author{
WANG JINGGUO* $\dagger$ and LARS R. BAKKEN $\ddagger$ \\ Department of Biotechnological Sciences, Agricultural University of Norway, P.O. Box 5040, N-1432 \\ Aas-NLH, Norway
}

(Accepted 5 October 1996)

\begin{abstract}
Summary-In an experiment where $\mathrm{N}$-poor (barley straw) and $\mathrm{N}$-rich (clover leaves) plant residues were placed into soil as separate layers, negative effect of plant roots on microbial growth was observed. The depression effect occurred predominantly in N-poor plant residue layers, which indicated that microbial growth can be limited by $\mathbf{N}$ availability in such microsites in soil. More energy substrates were available in the planted straw layer, as indicated by a significantly higher $\mathbf{N}$ immobilization potential in the planted soil compared with that in the unplanted soil. However, in the N-rich sites, plant roots stimulated $\mathrm{N}$ mineralization during $1 \mathrm{wk}$ incubation of soil slurries. Microbial response to initial growth conditions, including $\mathrm{C}$ and $\mathrm{N}$ availability, are also discussed. (C) 1997 Elsevier Science Ltd
\end{abstract}

\section{INTRODUCTION}

Soil microbial biomass as an $\mathrm{N}$ sink has been stressed (Paul and Juma, 1981), since microbial cells and metabolites are preferred substrates by active microorganisms clue to their low $\mathrm{C}$-to- $\mathrm{N}$ ratio of the chemical compositions (Jawson et al., 1989). Dead cells of microorganisms are easily decomposable, and based on this a biochemical method to estimate soil microbial biomass has been developed (Jenkinson, 1966; Jenkinson and Powlson, 1976a,b). The predation of microbes by protozoa and soil animals also stimulate mineral $\mathrm{N}$ release (Coleman et al., 1978; Elliotl et al., 1979; Clarholm, 1985). Some of the evidence has shown that, during the early stage of plant residue decomposition, when straw mixed with soil was incubated, most of the mineral $\mathrm{N}$ (labelled as ${ }^{15} \mathrm{~N}$ ) was immobilized into the fractions which are associated with microhial biomass (Cheng and Kurtz, 1963; Stewart et al., 1963; Jawson and Elliott, 1986). Under field conditions, Jackson et al. (1989) demonstrated that more than one-third of injected mineral $\mathrm{N}$ could be recovered in the microbial biomass fraction in a California grassland soil, within $24 \mathrm{~h}$ of incubation in situ.

*Present address: Department of Plant Nutrition, Beijing Agricultural University, Haidian, Beijing 100094, People's Republic of China.

† Author for correspondence.

${ }_{\ddagger}$ Present address: Department of Soil and Water Sciences, Agricultural University of Norway, PO Box 5028, N-1432, Aas-NLH, Norway.
Soil microorganisms are very active, provided that substrates are available. However, soil bacteria in general are oligotrophs, and the small cells ("dwarf cells") dominate due to limitation of available $\mathrm{C}$ and energy sources. Yet some investigations have also indicated that microbial growth in soil is limited by the availability of mineral nutrients rather than energy substrates in the rhizosphere (Helal and Sauerbeck, 1986; Merckx et al., 1987). In a growth experiment with groundwater bacteria, it was found that bacterial growth could be limited by phosphorus rather than by C (Bengtsson, 1989). In an investigation with plants in pots (Wang and Bakken, 1989) we found that microbial growth was depressed as a result of the competition for $\mathrm{N}$ between plant roots and the microflora.

Under a plant cover, the continuous flux of organic $\mathrm{C}$ materials from active plant roots represents a significant input of energy sources to the immediate soil, and sustains a larger community of rhizosphere microflora compared to that in bulk soil (Rovira and Davey, 1974). The flush of organic C, occurring with an amendment of plant residues, is another important $\mathrm{C}$ source for soil microorganisms. In both cases there must be some microsites where microbial growth may not be limited temporarily by energy substrate, rather but by mineral nutrients, especially $\mathrm{N}$ availability.

In the present study, with further refinement under the control conditions compared to a previous study (Wang and Bakken, 1989), soil microbial biomass and potential $\mathrm{N}$ mineralization or immobilization were determined, attempting to take 
the experiment one further step by looking at the microbial response to $\mathrm{N}$-depletion, resulting from the competitiveness of plant roots for mineralized $\mathrm{N}$.

\section{MATERIALS AND METHODS}

In a phytotron experiment (experiment 1 described in detail by Wang and Bakken, 1997) studying competition between plant roots and heterotrophic microflora for $\mathbf{N}$ during decomposition of plant residues in soil, bacterial numbers, hyphal lengths and potential $\mathrm{N}$ mineralization or immobilization in various soil samples were determined. Five treatments in the experiment were prepared with varying distance between $\mathrm{N}$-rich and $\mathrm{N}$-poor (C-rich) plant residues (clover leaves and barley straw). Then, barley plants were transplanted into the pots and the experiment was conducted under controlled conditions for $6 \mathrm{wk}$. Two weeks after planting, samples were taken every week. These soil samples were either composite samples from whole pots $\left(200 \mathrm{~g}\right.$ soil dry wt pot $\left.{ }^{-1}\right)$, or samples from the separate layers of straw or clover material plus adjacent soil (about $100 \mathrm{~g}$ of each). Later in the text, "clover layer" and "straw layer" refer to corresponding plant residue together with nearby soil (see Wang and Bakken, 1997 for more detailed information).

\section{Determination of microbial biomass}

Preparation of soil samples Roots were first separated from the soil by dry sieving $(2 \mathrm{~mm})$, and soil adhering to the roots was washed with two portions of $100 \mathrm{ml}$ distilled water (or $50 \mathrm{ml}$ distilled water for the separate layers), which were combined with the sieved soil into a slurry. Subsamples were taken from this slurry by a syringe during rapid stirring. The subsamples of soil slurries for biological analysis were homogenized further with a Warring Blender (three $1 \mathrm{~min}$ steps, cooled in ice periodically) and sampled for determination of bacterial numbers and fungal hyphal length.

Bacterial counts The numbers of bacterial cells were counted by fluorescence microscopy after staining with Acridine Orange (Acridine Orange Direct-Count, AODC); Hobbie et al. (1977). Separate counting within six different size groups was conducted (Bakken, 1985). The calculated mean cell volume $\left(\mu \mathrm{m}^{3}\right)$ in each size group were: I, 0.034; II, 0.11 ; III, 0.32 ; IV, 0.90 ; V, 2.35; VI, 6 . The biovolume was converted to biomass dry weight and $\mathrm{N}$ by assuming $0.33 \mathrm{~g} \mathrm{dry} \mathrm{wt} \mathrm{ml}^{-1}$ biovolume, and $12 \% \mathrm{~N}$ in biomass (Bakken, 1985).

Fungal counts Fungal hyphal length was measured by fluorescence microscopy, stained with fluorescein isothiocyanate I (FITC) and cross-points in a grid in the ocular were counted. The hyphae were divided into three diameter groups: $0-3,3-6$ and $>6 \mu \mathrm{m}$. Fungal biovolume was calculated separately for each group and combined. The fungal dry weight and $\mathrm{N}$ content was calculated assuming $220 \mathrm{mg}$ dry $\mathrm{wt} \mathrm{ml}^{-1}$ (Bakken and Olsen, 1983) and $4.5 \% \mathrm{~N}$ in fungal dry weight.

\section{$N$ mineralization or immobilization potential}

Soil $\mathrm{N}$ mineralization or immobilization potential was determined by measuring the increase or decrease in mineral $\mathrm{N}$ during a $1 \mathrm{wk}$ incubation of soil slurries, with or without the addition of nitrate prior to the incubation. Subsamples were taken as described above, and for each soil sample (slurry), four replicates of $150 \mathrm{ml}$ Erlenmeyer flasks containing $5 \mathrm{ml}$ slurry ( $3 \mathrm{~g}$ soil dry wt) were prepared. Control samples for determination of initial concentrations of mineral $\mathrm{N}$ were frozen immediately.

The flasks was either given $1 \mathrm{ml} \mathrm{Ca}\left(\mathrm{NO}_{3}\right)_{2}$ solution $\left(0.3 \mathrm{mg} \mathrm{NO}_{3}^{-}-\mathrm{N} \mathrm{ml}^{-1}\right)$ or $1 \mathrm{ml}$ distilled water prior to incubation. Nitrate was only given to those samples where net $\mathrm{N}$-immobilization was expected (straw layer and mixture of clover and straw layers).

All flasks were covered with aluminum foil and placed on a reciprocal shaker at $80 \mathrm{rev} \mathrm{min}^{-1}$ at $21^{\circ} \mathrm{C}$. A week later, the incubated and frozen slurries were extracted with $I \mathrm{M} \mathrm{KCl}$ solution (final concentration), and $\mathrm{NH}_{4}^{+-}$and $\mathrm{NO}_{3}^{-}-\mathrm{N}$ were determined using a flow injection analysis technique (FIA).

\section{Statistical analysis}

Standard statistical methods (analysis of variance, Stagraph) were used to test the effects of plant roots, distance between two plant residues and the interaction between these factors (samplings treated as blocks), and the effects were tested against a residual mean square.

\section{RESULTS}

\section{Microbial counts and biomass}

Bacterial counts and dry weight (average across treatments $\mathrm{C}-\mathrm{E}$ ) are shown in Fig. 1. As in a previous experiment (Wang and Bakken, 1989), plant roots had a negative effect on bacterial growth. Although the bacterial numbers were not significantly different between the planted and unplanted treatments [Fig. 1(a)], bacterial dry weight (DW) in the planted soil was significantly lower $(P=0.01)$ compared with that in the unplanted soil [Fig. 1(b)].

Bacterial counts and dry weight in the clover and straw layers (average across treatments $\mathrm{A}$ and B), are shown in Fig. 2. As expected, the negative effect of plant roots on bacterial growth occurred predominantly in the straw layers, and the difference in bacterial DW between the planted and the unplanted treatment was statistically significant $(P=0.01)$. 


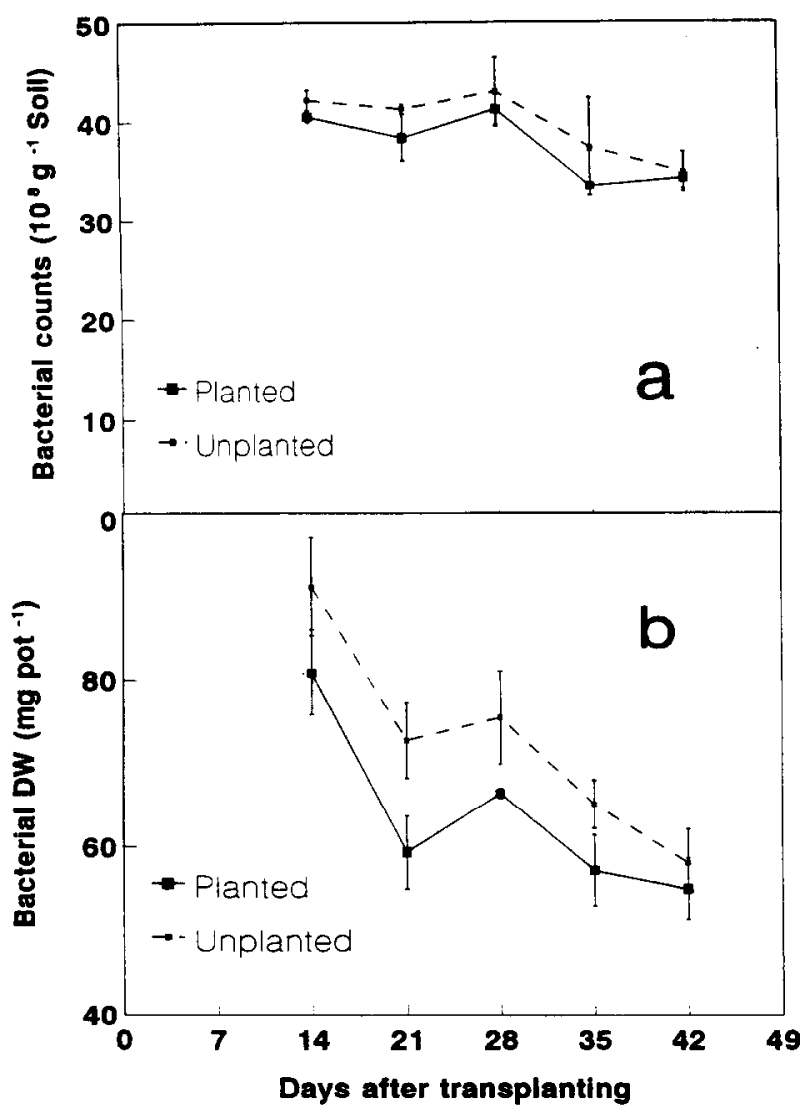

Fig. 1. The effect of plant roots on bacterial growth in the mixed layer samples, averaged across treatments C-E. (a) Bacterial counts; (b) biomass. Standard error shown as vertical bars $(n=3)$.

Bacterial biomess in each cell size group, averaged across treatments and samplings, is shown in Fig. 3. The difference in microbial biomass between the planted and the unplanted soil was attributed to the increase in the numbers of the large-celled bacteria (size groups III-V) in the mixed layer samples (treatments C-E, Fig. 3, upper part), and those large cells were major contributors to bacterial biomass in the soil. The bacterial numbers in cell size group VI were very low, and were of no significance to the total bacterial biomass. When the layers were separated, it was observed that the negative effect of plant roots on the growth of the large-celled bacteria occurred mainly in the straw layer (Fig. 3, lower part), whereas in the clover layer no such significant effect $(P=0.05)$ was observed (data not shown).

The fungal length and dry weight fungal biomass was a minor part of the total microbial biomass, and there was no significant difference at the $P=0.05$ level in fungal biomass between the planted and unplanted soil (data not shown).

For the separate layers (data not shown), it was observed that in the first four samplings fungal dry weight was only slightly lower in the planted straw layer compared to the unplanted straw layer.

\section{$N$ mineralization or immobilization potential}

Observed $\mathrm{N}$-mineralization or immobilization in the slurries during a week of incubation has been transformed to a "per pot basis", i.e. $\mathrm{mg} \mathrm{N}^{\mathrm{N}}$ pot $^{-1}$. The data presented are based on the sum of ammonium and nitrate $\mathrm{N}$. Most of the mineral $\mathrm{N}$ released during the incubation had been nitrified (data not shown)

Net N-mineralization or immobilization in incubated slurries of treatments C, D (layers not separated) and $\mathrm{E}$ (mixture) have been averaged, and are shown in Fig. 4. In the slurries with mineral $\mathrm{N}$ added, there was a high potential for immobilization throughout the whole experiment; significantly higher $(P=0.01)$ for the planted than for the unplanted soil. The slurries without nitrate $\mathrm{N}$ addition gave very low values for the planted soil $(\mathrm{N}$ immobilization potential exceeded the amounts of mineral $\mathrm{N}$ present); in the unplanted soil there was a gradual increase in net $\mathrm{N}$-mineralization.

Net $\mathrm{N}$ mineralization (in the clover layer) and immobilization (in the straw layer) during slurry incubation are shown in Fig. 5. As expected, straw and clover layers had considerable potentials for $\mathrm{N}$ immobilization and mineralization, respectively. Net $\mathrm{N}$ mincralization in the planted clover layer was sig- 


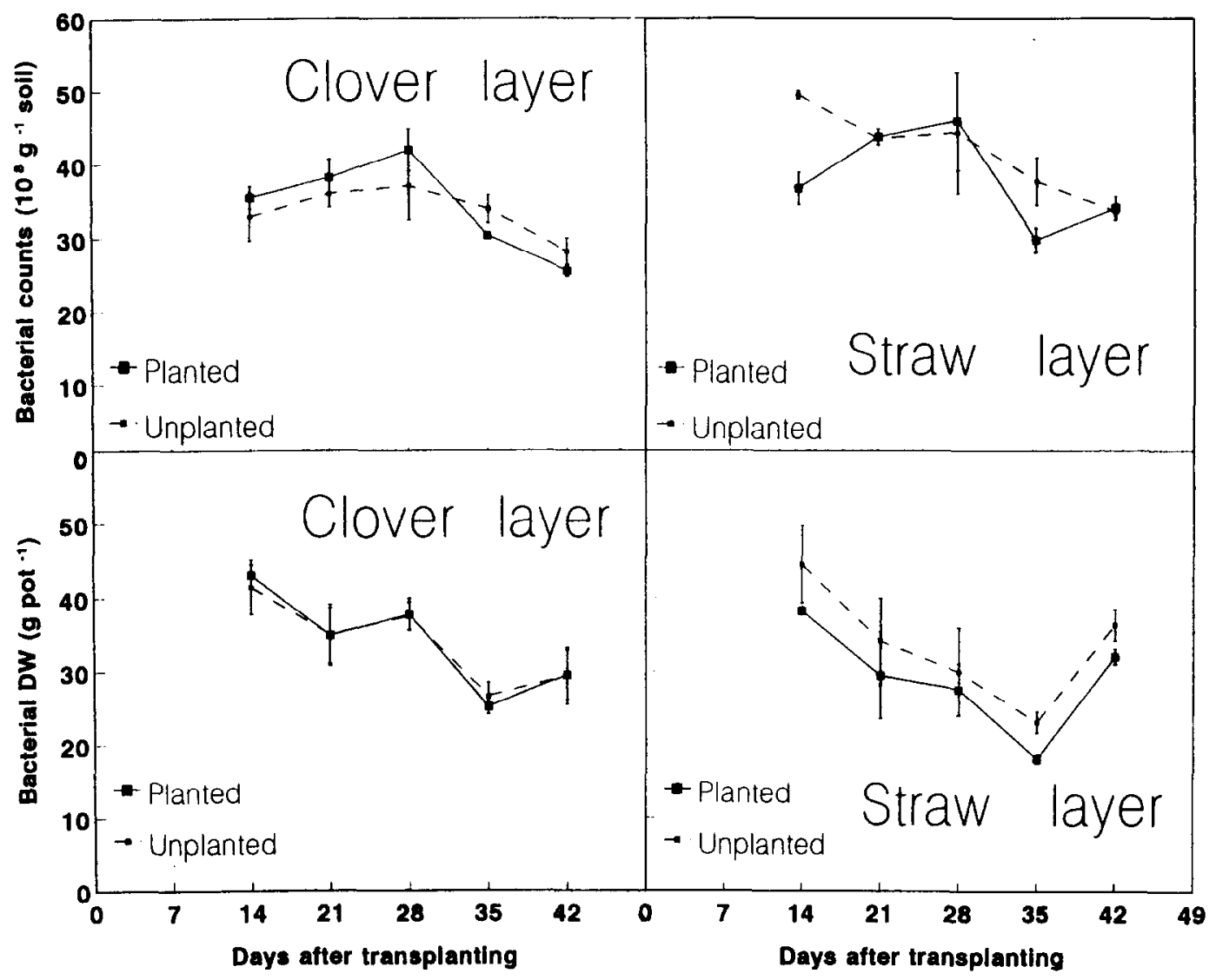

Fig. 2. The effect of plant roots on bacterial growth in the separate clover and straw layers, averaged across treatments A and B. Bacterial counts (upper part) and biomass (lower part), with standard error bars $(n=2)$.

nificantly higher $(P=0.01)$ than that in the unplanted clover layer, except at the first sampling (statistically significant at $P=0.01$ for each sampling). In the straw layer, there was a significantly higher $(P=0.05) \mathrm{N}$ immobilization potential for the planted than for the unplanted soil.

When the net $\mathbf{N}$ mineralization or immobilization is plotted against both bacterial counts and bacterial dry weight, there was only a slight positive effect of microbial biomass on $\mathrm{N}$ mineralization potential in the clover layer (data not shown). No other correlations between microbial biomass and $\mathrm{N}$ mineralization and immobilization were observed.

\section{Microbial $N$ turnover rate}

Microbial (bacterial) $\mathrm{N}$ turnover rate during a week of incubation in the separate layers has been calculated based on the following formula:

Turnover time (days) $=$

\section{bacterial $\mathrm{N} /$ net $\mathrm{N}$ mineralization \\ or immobilization $\mathrm{d}^{-1}$}

and the results are shown in Fig. 6. Initially, there was high microbial $\mathrm{N}$ turnover rate, in both the clover and the straw layers. As the plant residue decomposed, the turnover rates gradually decreased, especially for the unplanted clover layer. Towards the end of the experiment, the microbial $\mathrm{N}$ turnover rate also declined in the planted treatment.

\section{DISCUSSION}

Compared to the results of a previous greenhouse experiment (Wang and Bakken, 1989), fungal biomass was much lower (one-seventh to one-tenth of the prevous estimate). Because we had to use low soil dilutions there were more soil particles on the membrane filters. This made it difficult for us to measure the fungal length accordingly.

Normally, microbial growth in soil has been thought to be limited by energy substrates rather than mineral nutrients. However, the evidence, provided in Fig. 1, suggested that $\mathbf{N}$ availability can also be a limiting factor for soil microbial growth. The significantly lower microbial biomass in the planted soil compared with that in the unplanted soil clearly demonstrated that the microbial growth was limited by plant roots, and the limiting factor was the $\mathrm{N}$-depletion created by plant root uptake of 


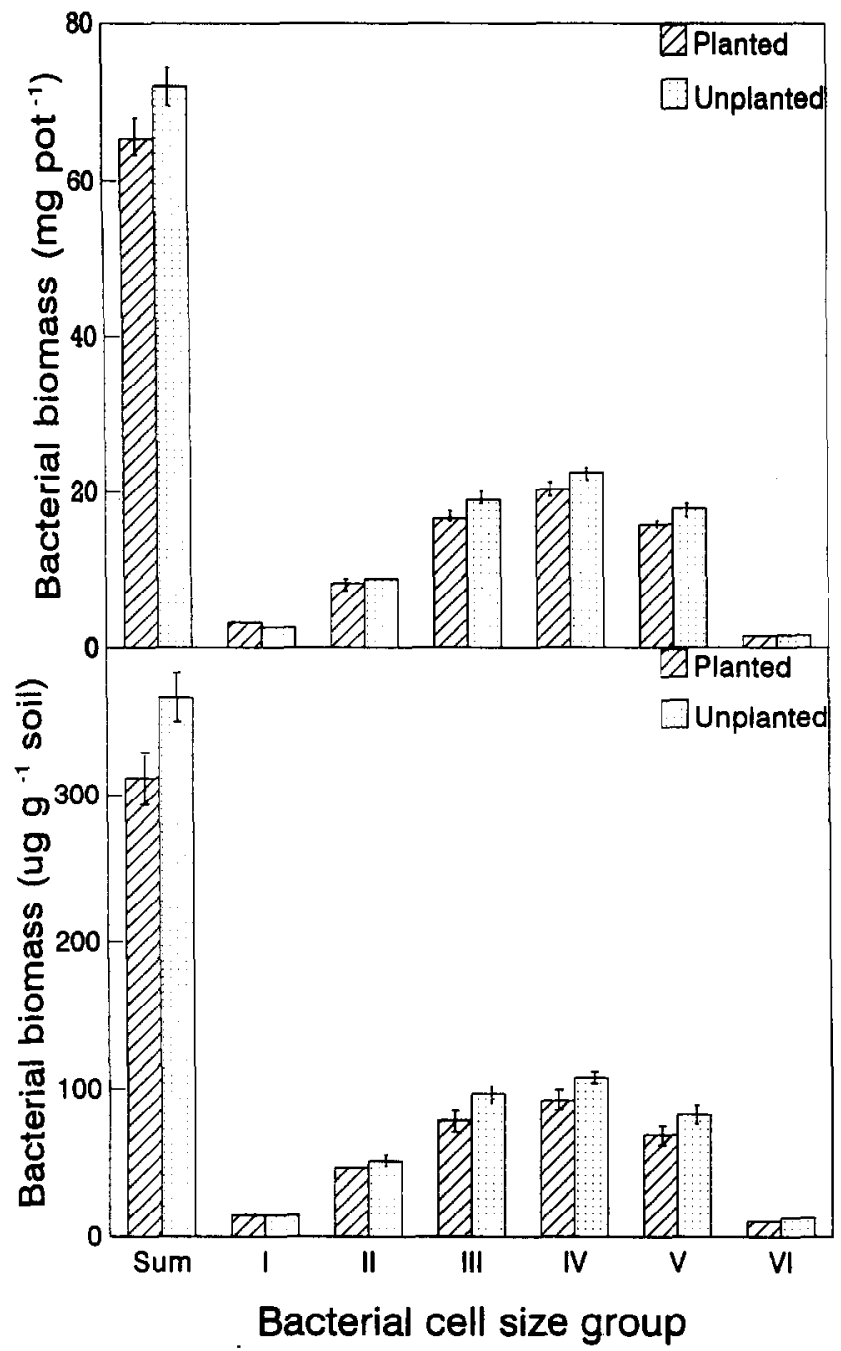

Fig. 3. Bacterial cell size distributions, as affected by plant roots. The data has been averaged across treatments $\mathrm{C}-\mathrm{E}$ and samplings for the mixed layer samples (above, $n=15$ ), and averaged across treatments $\mathrm{A}$ and $\mathrm{B}$, and samplings for straw layer (below, $n=10$ ).

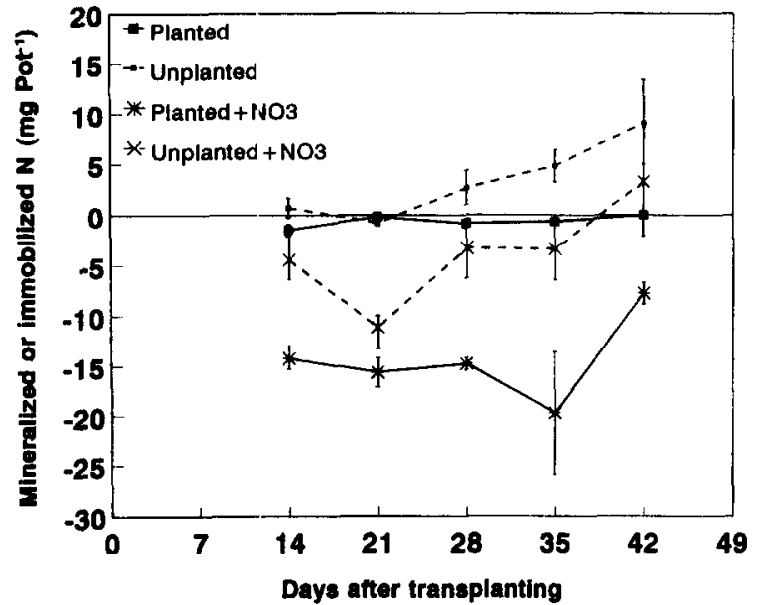

Fig. 4. $\mathrm{N}$ Mineralization and immobilization during 1 wk incubation of soil :lurries with both straw and clover treatments C-E (the data averaged across these treatments), as affected by plant roots and nitrate addition, with standard error bars $(n=3)$.

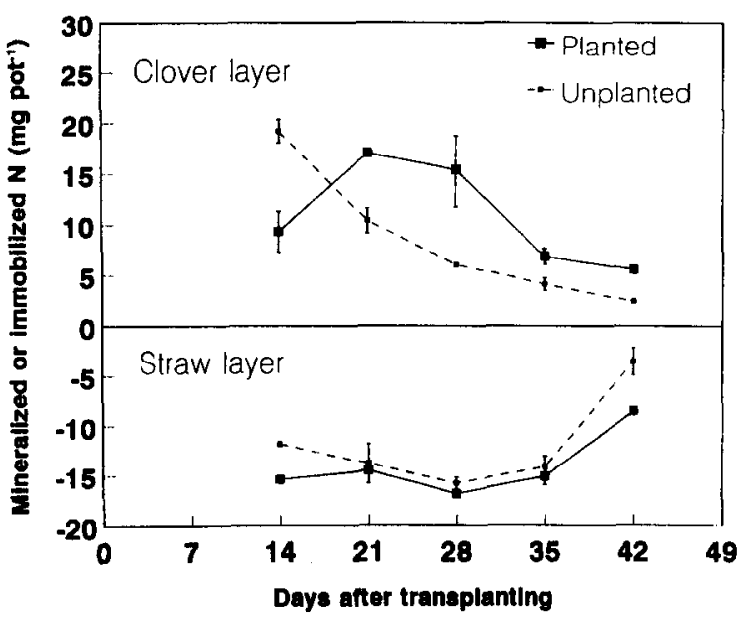

Fig. 5. $\mathrm{N}$ mineralization or immobilization (average across treatments $A$ and $B$ ) during 1 wk incubation of soil slurries, as affected by types of plant residues and plant roots. Nitrate was only added to the slurries sampled from straw layer. Standard error bars are shown $(n=2)$. 


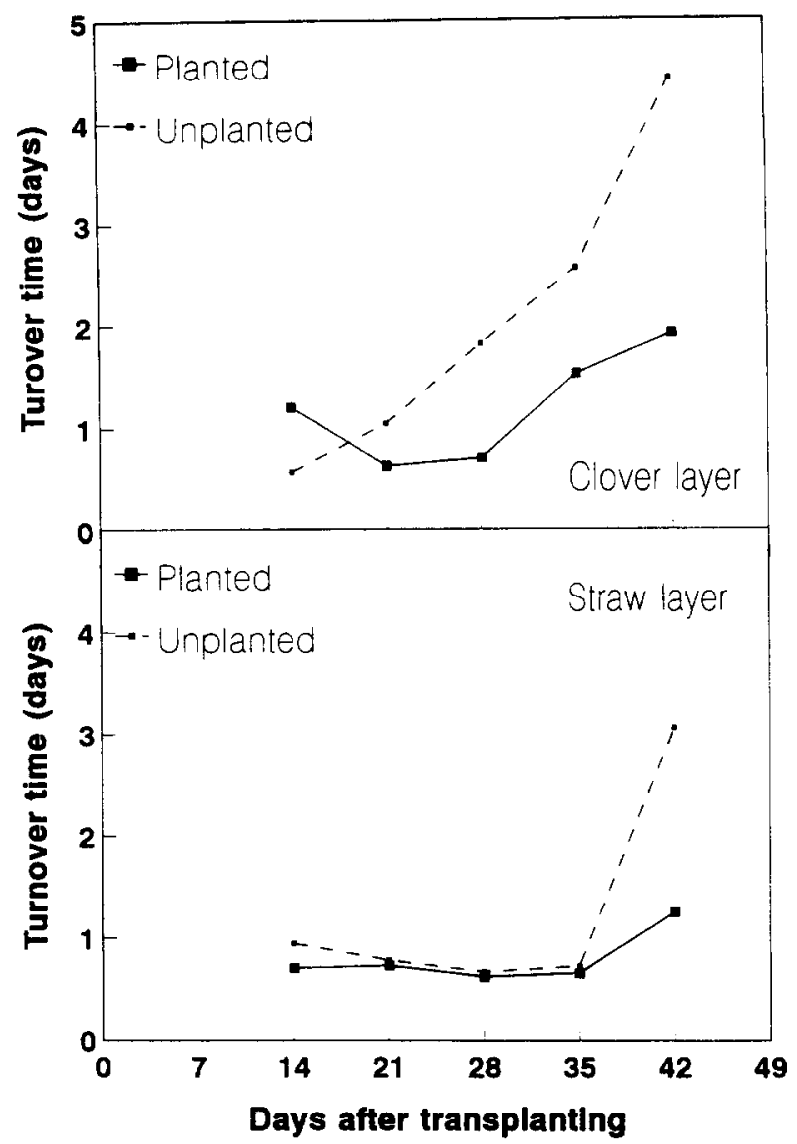

Fig. 6. Estimated turnover time of microbial $\mathrm{N}$ in the slurries: bacterial $\mathrm{N}$ divided by the net $\mathrm{N}$-mineralization (clover layers) or $\mathrm{N}$-immobilization (straw layers) per day

mineralized N (Wang and Bakken, 1997). As shown in Fig. 2, the depressing effects of plant roots principally occurred in the straw layer. A significantly higher $\mathrm{N}$ immobilization potential in the planted straw layer was observed (Fig. 5). Therefore the competitiveness of plant roots for mineralized $\mathrm{N}$ had induced a more severe $\mathrm{N}$ stress condition for the microorganisms at the $\mathrm{N}$-poor sites. Our study agrees well with the previous investigation carried out in a greenhouse (Wang and Bakken, 1989). With the further refinement in the present study, it has been confirmed that $\mathrm{N}$ availability is actually more important than $\mathrm{C}$ availability in the promotion of microbial biomass production at some microsites in soil. Our results thus verified the hypothesis that microbial growth in soil can be limited by nutrient supply, as suggested by Sparling et al. (1982), Helal and Saucrbcck (1986) and Merckx et al. (1987).

The depressing effect of plant roots on bacterial growth in the straw layer and the mixed soil samples occurred predominantly for the large-celled bacteria (Fig. 3), as was also shown by Wang and Bakken (1989). This seems contradictory to the general view that $\mathbf{C}$ starvation induces a reduction of the size of bacterial cells. As suggested by
Kjelleberg et al. (1983) and Moyer and Morita (1989), the size reduction of the C-starved cells was common for Gram-negative marine bacteria. For soil bacterial isolates, Luscombe and Gray (1974) demonstrated that the rod-type cells of four arthrobacter strains divided and produced cocci during $\mathrm{C}$ starvation. The dwarf cells are normally thought of as survivors or survival stage during energy limitation (Shnürer et al., 1985; Bakken and Olsen, 1986)

However, changes in the relative concentrations of large bacterial cells might also reflect the nutritional status in the environment. The effect of nutritional status, for instance $\mathrm{N}$ stress in our case, on bacterial growth may not be direct, but rather indirect. The significantly higher potential $\mathrm{N}$ immobilization induced by plant roots indicated that $\mathrm{C}$ substrates were more abundant in the planted soil than that in the unplanted soil. However, those C substrates probably consisted of polymers and were not readily available to the bacteria. Therefore it would be necessary for the microorganisms to produce extracellular enzymes for utilization of the polymers. It was more likely, in our present study, that the synthesis of the exoenzymes was stressed more severely by $\mathbf{N}$ availability in the planted soil 


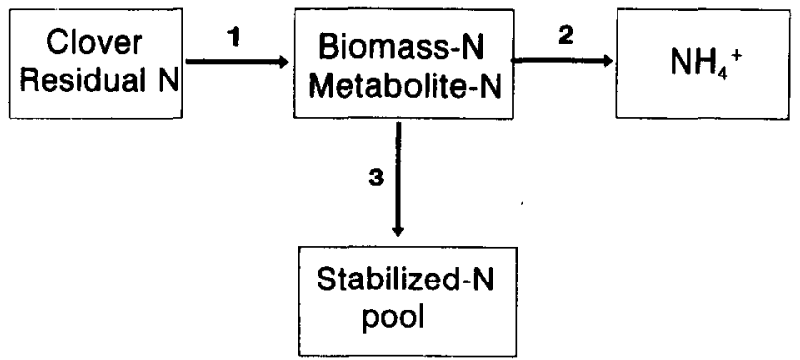

Fig. 7. Scheme of the relation among possible $\mathrm{N}$ pools derived from clover.

compared to the unplanted soil, and consequently an inefficient use of energy substrate.

Regarding $\mathrm{N}$ mineralization potential in the clover layer, somewhat unexpected results occurred. To facilitate the discussion, a scheme is prepared and shown in Fig. 7. The observation that the soil organic $\mathbf{N}$ was practically identical (Wang and Bakken, 1997) in both the planted and unplanted clover layer shows that plant roots had a negligible effect on the overall net $\mathrm{N}$-mineralization (2) in the layer. However, the potential $\mathrm{N}$-mineralization in slurries of clover layers was substantially higher (except in the first sampling) for the planted than for the unplanted soil, indicating that more $\mathrm{N}$ was present in a labile form in these pots. These two observations taken together indicate that the plant roots had either stimulated the decomposition rate (1) or reduced the stabilization of N (3). One mechanism of $\mathrm{N}$-stabilization which might be affected by plant root uptake of mineral $\mathbf{N}$ is the reaction between nitrite and organic material (Azhar et al., 1986). Further investigation is required to clarify the phenomena.

Microbial bionass could hardly be taken as an indicator of the extra mineralizable $\mathrm{N}$ in the planted clover layers. Firstly, there was no clear link between microbial biomass and $\mathrm{N}$ mineralization or immobilization potential in treatments where straw and clover layers were mixed (treatments $\mathrm{C}-\mathrm{E}$ ), and a slight positive correlation between microbial biomass and $\mathrm{N}$ mineralization potential only occurred in the clover layer (data not shown). Secondly, the variation of size of microbial biomass was not clearly coincident with the variation of amount of $\mathrm{N}$ released during the incubation of soil slurries. Thirdly, the microbial $\mathrm{N}$ turnover rate changes with type of plant residues and the time they take to decompose.

As stated earlier, soil bacteria are living in starvation conditions with occasional flushing of energy substrates from plant roots and amendment of plant residues. When ample $\mathrm{C}$ materials are readily available, bacteria take up organic $\mathrm{C}$ for growth, and some of them even have unbalanced growth, including production of some storage materials, such as poly- $\beta$-hydroxybutyric acid (PHB), uncoupling respiration (Dawes, 1989) and bacterial cell size enlargement (Morita, 1988), not necessarily with storage materials present. In our present study it could have occurred immediately after amendment with barley straw. In a situation like this, microbial biomass could hardly be related to any net $\mathbf{N}$ mineralization; rather a net $\mathbf{N}$ immobilization (in straw laycr) if $\mathrm{N}$ was available. This is in contrast to the clover layer, where there was a slight correlation between microbial biomass and total $\mathrm{N}$ mineralization. It seemes that the initial growth conditions, including $\mathrm{C}$ and $\mathrm{N}$ availability, rather than microbial biomass were decisive, since in time, $\mathrm{N}$ mineralization or immobilization potential decreased (Figs 4 and 5).

Obviously, the microbial $\mathrm{N}$ turnover rate was affected by plant roots in the present experiment as shown in Fig. 6, especially in the clover layer, where no difference in microbial biomass was found (Fig. 2). This demonstrates clearly that the part of active microorganisms, rather than total microbial community, determined potential $\mathrm{N}$ mineralization or immobilization. Also, stimulation of microbial activity by plant release of organic $\mathrm{C}$ materials might have occurred in the planted pots.

\section{REFERENCES}

Azhar E.S., van Cleemput O. and Verstraete W. (1986) Nitrification mediates nitrogen immobilization in soils. Plant and Soil 94, 401-409.

Bakken L.R. (1985) Separation and purification of bacteria from soil. Applied and Environmental Microbiology 49, $1482-1487$.

Bakken L.R. and Olsen R.A. (1983) Buoyant densities and dry-matter contents of microorganisms: conversion of a measured biovolume into biomass. Applied and Environmental Microbiology 45, 1188-1195.

Bakken L.R. and Olsen R.A. (1986) Dwarf cells in soil-a result of starvation of "normal" bacteria, or a separate population. In Perspectives in Microbial Ecology (F. Megusar and M. Gantar, Eds), Proceeding of the Fourth International Symposium on Microbial Ecology, pp. 561566. Slovene Society for Microbiology, Ljubljana.

Bengtsson G. (1989) Growth and metabolic activity in groundwater bacteria. Microbial Ecology 18, 235-248.

Clarholm M. (1985) Interaction of bacteria, protozoa and plants leading to mineralization of soil nitrogen. Soil Biology and Biochemistry 17, 181-187.

Cheng H.H. and Kurtz L.T. (1963) Chemical distribution of added nitrogen in soils. Proceedings of the Soil Science Society of America 27, 312-316. 
Coleman D.C., Anderson R.V., Cole C.V., Elliott E.T., Woods L. and Campion M.K. (1978) Trophic interaction in soil as they affect energy and nutrient dynamics. IV. Flows of metabolic and biomass carbon. Microbial Ecology 4, 373-380.

Dawes D.E. (1989) Growth and survival of bacteria. In Bacteria in Nature: Structure, Physiology, and Genetic Adaptability (J. S. Poindexter and E. R. Leadbetter, Eds), Vol. 3, pp. 67-188. Plenum, New York.

Elliott E.T., Coleman D.C. and Cole C.V. (1979) The influence of amoebae on the uptake of nitrogen by plants in gnotobiotic soil. In The Soil-Root Interface (J. L. Harley and R. R. Scott-Russell, Eds), pp. 221-229. Academic, London.

Helal H.M. and Sauerbeck D. (1986) Effects of plant roots on carbon metabolism of soil microbial biomass. Zeitschrift fur Pflanzenernährung Bodenkunde 149, 181188.

Hobbie J.E., Daley R.J. and Jasper S. (1977) Use of nucleopore filters for counting bacteria by fluorescence microscopy. Applied and Environmental Microbiology 33, $1225-1228$.

Jackson L.E., Schimel J.P. and Firestone M.K. (1989) Short-term partitioning of ammonium and nitrate between plants and microbes in an annual grassland. Soil Biology and Biochemistry 21, 409-415.

Jawson M.D. and Elliott L.F. (1986) Carbon and nitrogen transformations during wheat straw and root decomposition. Soil Biology and Biochemistry 18, 15-22.

Jawson M.D., Elliott L.F., Papendick R.I. and Campbell G.S. (1989) The decomposition of ${ }^{14} \mathrm{C}$-labelled wheat straw and ${ }^{15} \mathrm{~N}$-labelled microbial material. Soil Biology and Biochemistry 21, 417-422.

Jenkinson D.S. (1966) Studies on the decomposition of plant material in soil. II. Partial sterilization of soil and the soil biomass. Journal of Soil Science 17, 280-302.

Jenkinson D.S. and Powlson D.S. (1976a) The effect of biocidal treatments on metabolism in soil. I Fumigation with chloroform. Soil Biology and Biochemistry 8, 167177.

Jenkinson D.S. and Powlson D.S. (1976b) The effect of biocidal treatments on metabolism in soil. V. A method for measuring soil biomass. Soil Biology and Biochemistry 8, 209-231.

Kjelleberg S., IIumphrey B.A. and Marshall K.C. (1983) Initial phase of starvation and activity of bacteria at surfaces. Applied and Environmental Microbiology 46, 978-984.

Luscombe B.M. and Gray T.R.G. (1974) Characteristics of arthrobacter grown in continuous culture. Journal of General Microbiology 19, 210-222.

Merckx R., Dijkstra A., den Hartog A. and van Veen J.A. (1987) Production of root-derived material and associated microbial growth in soil at different nutrient levels. Biology and Fertility of Soils 5, 126-132.

Moyer C.L. and Morita R.Y. (1989) Effect of growth rate and starvation-survival on the viability and stability of a psychrophilic marine bacterium. Applied and Environmental Microbiology 55, 1122-1127.

Morita R.Y. (1988) Bio-availability of energy and its relationship to growth and starvation survival in nature. Canadian Journal of Microbiology 34, 436-441.

Paul E.A. and Juma N.G. (1981) Mineralization and immobilization of soil nitrogen by microorganisms. In Terrestrial Nitrogen Cycles (F. W. Clark and T. Rosswall, Eds.), Ecological Bulletin (Stockholm), Vol. 33, pp. 179-195.

Rovira A.D. and Davey C.B. (1974) Biology of the rhizosphere. In The Plani Root and Its Environment (E. W. Carson, Ed.), pp. 153-204. University Press of Virginia, Charlottesville.

Shnürer J., Clarholm M. and Rosswall T. (1985) Microbial biomass and activity in an agricultural soil with different organic matter contents. Soil Biology and Biochemistry 17, 1059-1066.

Sparling G.P., Cheshire M.U. and Mundie C.M. (1982) Effect of barley plants on the decomposition of ${ }^{14} \mathrm{C}$ labelled soil organic matter added as ryegrass. Journal of Soil Science 33, 89-100.

Stewart B.A., Porter L.K. and Johnson D.D. (1963) Immobilization and mineralization of nitrogen in several organic fractions of soil. Proceedings of the Soil Science Society of America 27, 302-304.

Wang J.G. and Bakken L.R. (1989) Nitrogen mineralization in rhizosphere and non-rhizosphere soil, effect of the spatial distribution of N-rich and N-poor plant residues. In Nitrogen in Organic Wastes Applied to Soils (J. A. Hansen and K. Henriksen, Eds), pp. 81-97. Academic, London.

Wang J.G. and Bakken L.R. (1997) Competition for nitrogen during decomposition of plant residues in soil: effect of spatial placement of $\mathrm{N}$-rich and $\mathrm{N}$-poor plant residues. Soil Biology and Biochemistry 29, 153-162. 